\title{
Literature Synthesis for Assessment and Management of Seagrasses
}

\author{
Cherry C. Favor \\ Southern Luzon State University-Judge Guillermo Eleazar \\ Tagkawayan, Quezon \\ ORCID\#0000-0003-4317-1847
}

\begin{abstract}
This paper collates seagrass studies from 2008-2017. The focus of review is on the studies conducted in Philippines and in some areas of world in relation to this dynamic and most productive marine ecosystem the seagrass meadows. The review reveals that there is an abundance in diversity, distribution and cover of seagrass in different parts of the country, wherein articles written in other part of the world provides data and information on physical, biological and economic importance of Seagrass in the human lives. The cause of its destruction was found out to be mostly anthropogenic activities. Limitations on the conducted studies in the Philippines was shown as reflected in the collected studies that are generally done along the coastal areas in the Visayas and Mindanao regions. Which practically shows an opportunity to explore different places in Luzon for an assessment of Seagrass for its ecosystem resiliency, stability, management and sustainability. Foreign studies included in the review reflects studies on assessment of biophysical characteristics of the seagrasses with the use of modern technologies like remote sensing and management practices that illustrates market value of ecosystem services of seagrass meadows on its application for some small-scale fisheries. Knowledge gap on socio-ecological importance of seagrasses, economic valuation of this marine habitat ecosystem services and wake up call for policy maker to consider seagrasses in their proposal for management shift of this ecologically significant habitat are topics needing further investigations.
\end{abstract}

Keywords- literature review, marine habitat, research opportunity.

\section{Introduction}

Humanity depends on the Earths' ecosystem for its provision for food, water and raw materials, climate regulations and storm protections. (Unsworth, LCC and Unsworth, RKF, 2013). The coastal zone is the interface where the land meets the sea and considered to be the most productive part of the planet, approximately it provides $25 \%$ of the global primary productivity and estimated $90 \%$ of the global catch (Shan, et al., 2016). Historically oceans are believed to be limitless and can harbor enough fish to feed the growing population. Unfortunately, the demands of the growing population outstrip the sustainable yield of the sea (Tidwell, JH and Allan, GL., 2001). As estimated by United Nations Department of Economics and Social Affairs (UN-DESA, 2009) the world is expected to have its population grows to 9 billion by 2050. With the increasing human population, alteration of worlds' ecosystem was rapidly and largely to meet the demand for food, water and raw materials. This dependence on natural resources is very high specially in the developing countries and the essential contribution of the fisheries sector is of utmost importance to ensure adequate supplies of food and the source of economic and social progress Castro et al, (2014), Hotta, (2003).

Fishery resources is a good source of vitamins and micronutrients that are essential for human wellbeing, thus paying attention for its sustainability, protection, conservation and improvement of its current status is due and demandable to ensure sustainable harvest and conservation of its biodiversity. (Garcia, SM and Rosenberg, AA, 2010). The three distinction ecosystem of this fishery resources are mangrove forest, coral reefs and the seagrass meadows which are interconnected with each other that takes place along the entire seascape. (Jin, 2014, Castro, et al. 2014). 


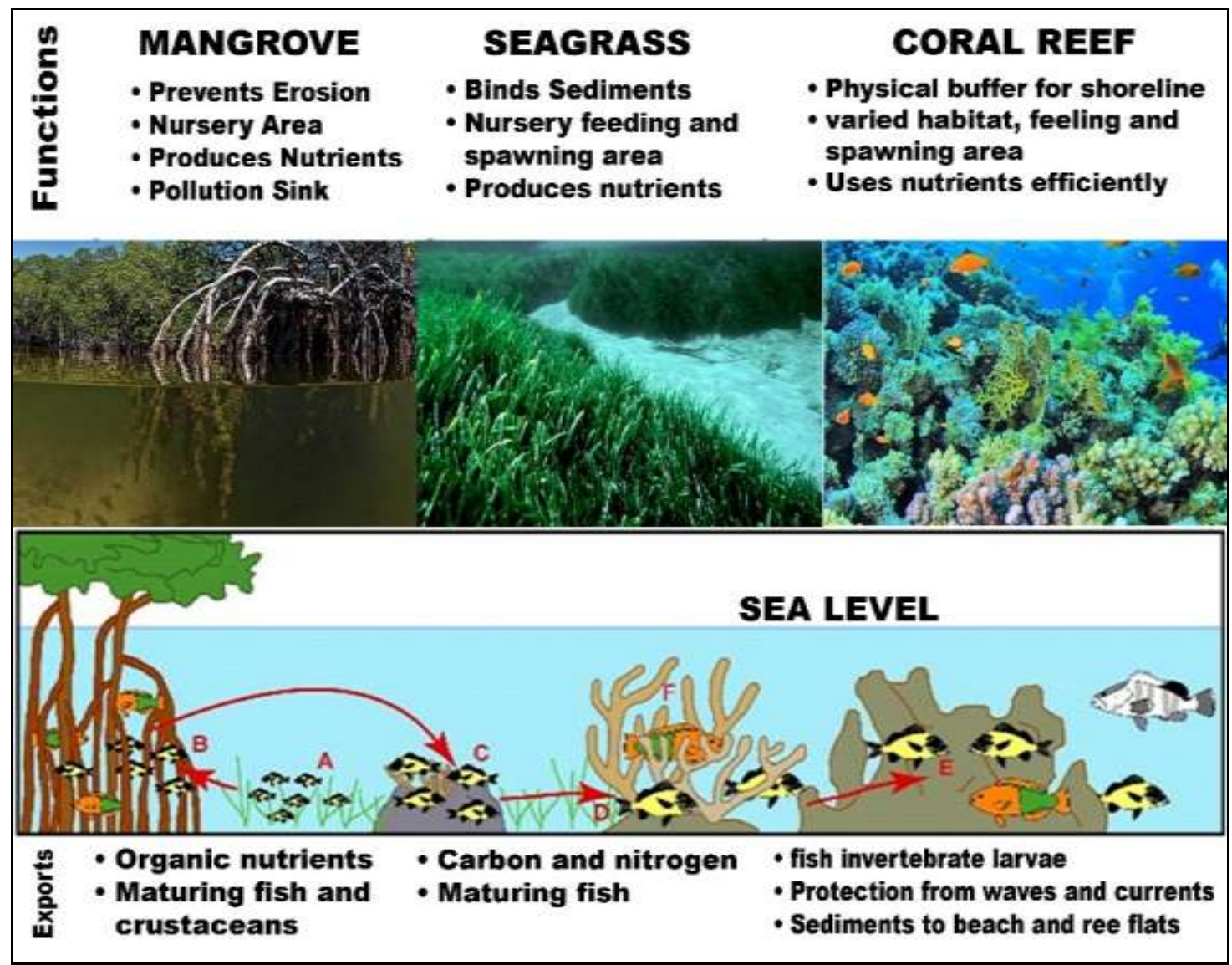

Photo credit to the owner

Figure 1. The Interconnection of the Marine Ecosystems.

Seagrasses are known as specialized marine flowering plants that are monocotyledonous which develops fruit and seed, have true roots and have internal gaseous and nutrient transport systems. (Alberto et al., 2015, Orbita, MLS and Gumban , NB, 2013, Unsworth, LCC and Unsworth, RKF, 2013). A marine angiosperm that are attached to all types of substrates that occurs extensive on soft ones and thriving best in slightly reducing sediments of shallow tropical and subtropical coast and commonly found in intertidal region up to 30 meters in depth. (Fortes, 2012, Alberto et al, 2015, Selorio, 2009).

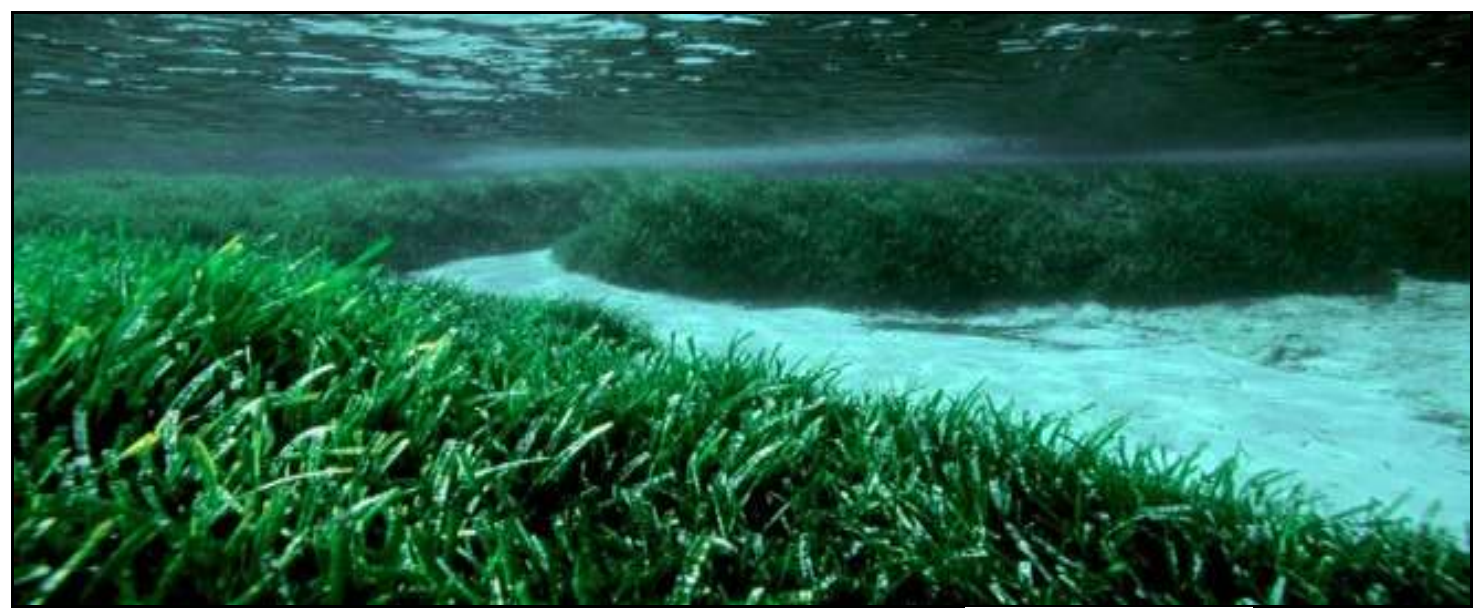

Figure 2. Seagrass Meadow of Posidonia oceanica Credit: M. San Felix 
It supports diverse community in marine waters by feeding, breeding, and as a nursery grounds for marine organisms like fishes, marine animals that endangered and other large vertebrates in the sea. Like terrestrial grasses do it has the ability to reproduce underwater, supply oxygen, stabilized sand and mud banks. (Jumawan, et al., 2015). Some of the special features of seagrasses are, it has a high carbon sequestration and phytoremediation potentials that are essential for sustainability of the marine ecosystem (Alberto et al, 2015 and Jumawan et al. 2015).

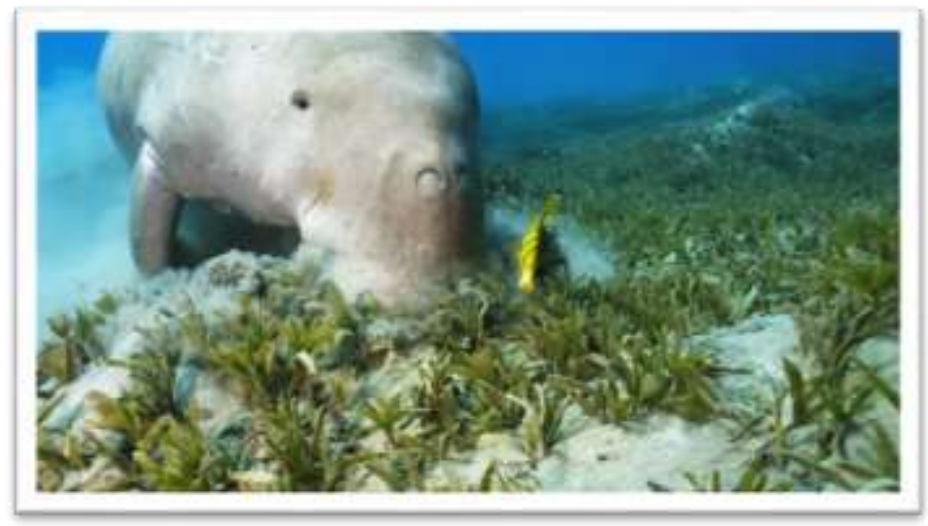

Photo Credit : Dugong and Cleaner Fish on Seagrass. David Peart/arabianEye/Getty Images

Figure 2. Marine animal feeding and inhabiting in seagrasses

Its unique ecological function plays an important role in the estuarine and marine ecosystem, it linked the other ecosystem to each other to equilibrate marine coastal environment (Fortes, 2010, Alimen et al., 2010). Aside for those profitable benefits seagrasses can provide wide range of ecosystem services a natural process that directly or indirectly benefit humans. (Nordlund, et al., 2017)

Special cells within the seagrass, called chloroplasts, use energy from the sun to convert carbon dioxide and water into carbohydrates (or sugar) and oxygen through photosynthesis. The roots and rhizomes of the seagrass absorbs and stores nutrients to be able to be stable under water. (Cullen-Unsworth et al, 2018). Seagrasses are at a disadvantage of gaining awareness to the general public attention, although of the same ecological importance like the mangrove and Coral reefs ecosystem, it was left out with the little knowledge by the public of the benefits they provide, resulting to become unappealing and least studied. For this, seagrasses are found to be disappearing at a rate of $110 \mathrm{~km}^{2} / y e a r$ and from the initial record in 1879 with $29 \%$ of the known areal extent it disappeared, and in the recent year an estimated $7 \%$ decline rate are observed globally for its loss and destructions. (Nordlund et al, 2017). This is equivalent to the size of a two football fields lost every hour (Duarte, C. M.et al 2009) This decline in seagrass meadows and coverage was observed worldwide due to the combination of environmental changes such as physical parameters (temperature, salinity, and $\mathrm{pH}$ ), natural phenomena (tidal effects, cyclone, and seasonal changes) and anthropogenic activities such as coastal development (where new buildings are constructed along the coast), pollution of rivers and other water bodies that flow into the sea, and the removal of too many marine animals (overfishing) (Cullen-Unsworth et al., 2018). Thus, exploitation, lack of knowledge and information, siltation and destructive gleaning practices contributed largely on the destruction and declining of this habitat condition (Jumawan et al., 2015)

One of the prominent component in the coastal ecosystem are the seagrasses. (Fortes 1995). Out of the known 69 species of seagrasses in the world, eighteen species were found in the Philippines (Fortes, 2012, Iswandi Wahab et al., 2017), the second most diverse in number of seagrasses in the world (Padilla, 2008).

The Philippines has an estimated 36,289 kilometers coastlines, that extends 2,000 kilometers from north to south with major cities lying on the coast and it is estimated that $60 \%$ total population is living in the coastal area. (Asian Development Bank, 2014). Ranked $12^{\text {th }}$ among the fish capturing nations worldwide, Philippine seagrass ecosystem becomes the revenue for daily income and other ecosystem services. (Honda, et al., 2013) 
Thus, this study attempts to find out what was already been written about seagrasses in the different parts of the world and more specific in the Philippines about assessment, status and management of this marine habitat. With the following objectives:

a. Review articles written about seagrasses in the past 10 years.

b. Enumerate studies conducted for assessment and management of seagrasses.

c. Identify gap and opportunity for future studies on seagrasses.

\section{Methodology:}

This paper utilized a qualitative analysis of paper that was written in the past 10 years about seagrasses. Some criteria have been set for screening of the paper for inclusion and exclusion in the review process. Terminologies for the search of articles was carefully been selected and identified as words to look for under the chosen topic that includes, biodiversity, abundance, status, distribution, assessment, Philippines and management. Full paper of the articles was retrieved for further verification of the unclear information cited for validation and authentication of data.

\section{FRAMEWORK}

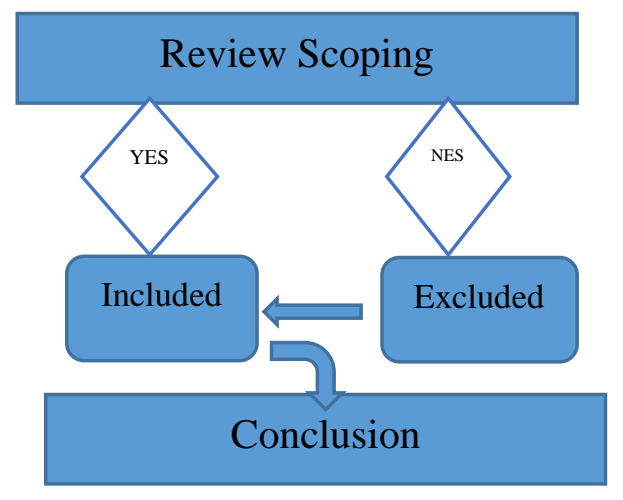

The foundation of all literature review lies of the two things its process and the output made out of comparing different ideas in a pool of written article in a chosen area of study. That serves the driving force and the jumping area to start up a new investigation Ridley (2008). For the process it includes the a frame that will define and leads to the concept that maps the terrain of the research that systematized relationships of the ideas that will conclude the literature gaps in the analysis of the written article under review(Tonette S. Rocco and Maria S. Plakhotonik, 2009).

III. Results

Several studies have been searched for inventory and assessment of the status this important marine habitat a are presented in the table below 


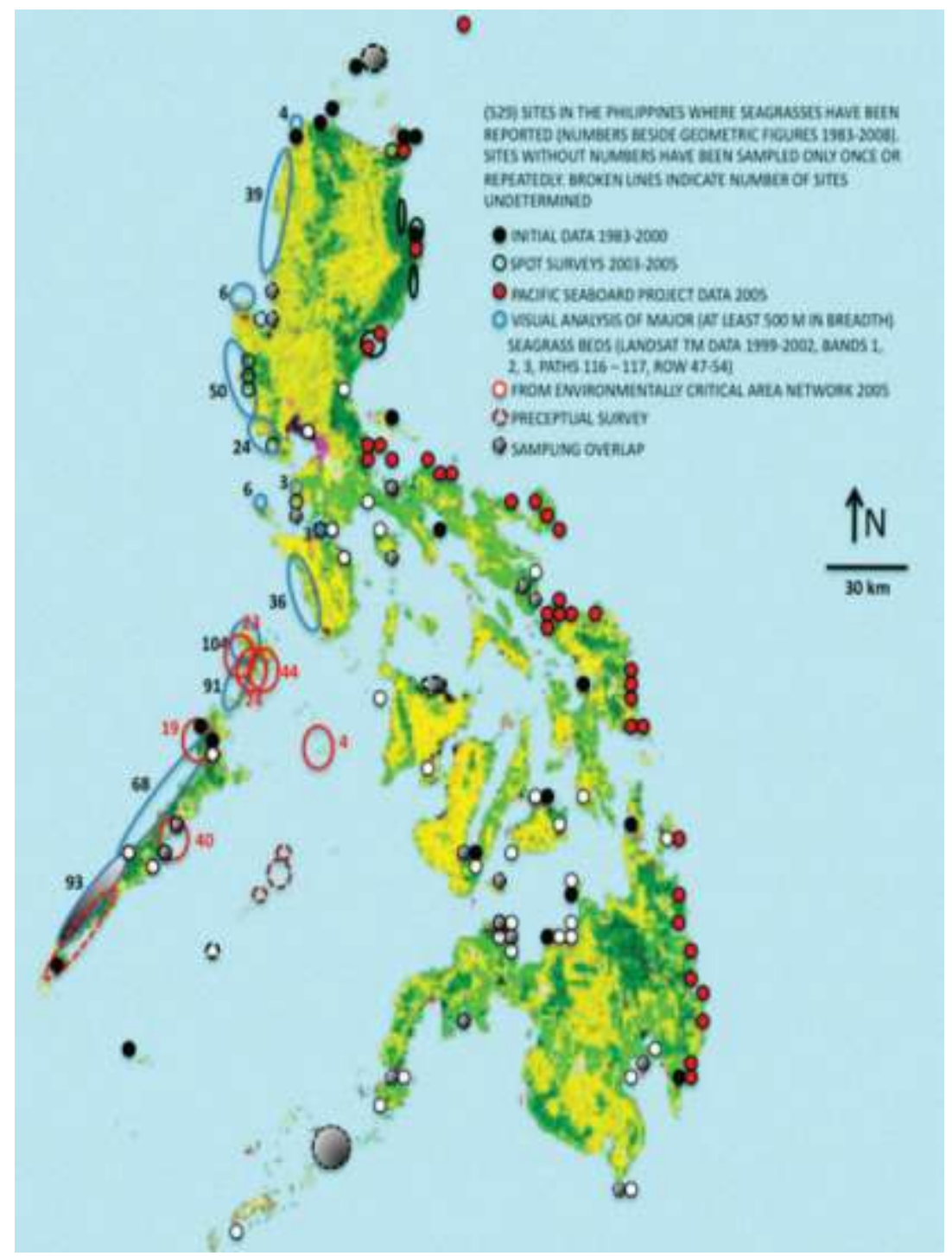

Figure 4. 1983 to 2012 Inventory of Seagrass Meadow in the Philippines (Fortes, 2013)

Table 1. Studies Conducted for assessment of seagrasses

\begin{tabular}{|c|c|c|}
\hline Studies & Finding and conclusion & Authors \\
\hline $\begin{array}{l}\text { Spatial evaluation of intertidal } \\
\text { seagrass field using optical } \\
\text { imaging systems and a } \\
\text { frivolous drone. }\end{array}$ & $\begin{array}{l}\text { For seagrass conservation effort the use of lightweight drones and miniaturization of } \\
\text { sensors for optical remote sensing will be crucial to investigate the fragmentation } \\
\text { within the seagrass meadows, which can inform researchers and managers whether this } \\
\text { part of the seagrass beds is potentially degrading or recovering, hence will soon allow } \\
\text { for more detailed measurements of meadow quality such as plant health and presence } \\
\text { of wasting disease based on the spectral signatures obtained from seagrass shoots. }\end{array}$ & $\begin{array}{l}\text { James } \\
\text { P.Duffy }{ }^{\mathrm{a}} \text { LauraPratt }{ }^{\mathrm{bc}} \text { KarenAnderson }^{\mathrm{a}} \text { Peter } \\
\text { E.Land }{ }^{\mathrm{d} J a m i e} \text { D.Shutler } \\
\end{array}$ \\
\hline $\begin{array}{l}\text { Current state of seagrass } \\
\text { ecosystem services: Research } \\
\text { and policy integration }\end{array}$ & $\begin{array}{l}\text { There are gaps on the knowledge of ecosystem services provided by the seagrasses, } \\
\text { and thru operationalization of the SGES (Seagrasses ecosystem services) evaluations, } \\
\text { identification of areas to be studied were more on the geographical, type of service and } \\
\text { discipline biases as the focus of expansion for researches on seagrasses beds. }\end{array}$ & $\begin{array}{l}\text { A. Ruiz-Fraua, *, S. Gelcichb , I.E. } \\
\text { Hendriksa, C.M. Duartec , N. Marbà } \\
\text { ( 2017), }\end{array}$ \\
\hline
\end{tabular}




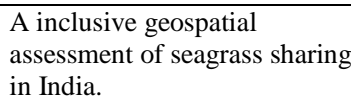

Distribution and Abundance of Seagrasses Bontoc, Southern Leyte Seagrass beds of Palawan
Status Monitoring of Palawan

The use of digital mapping using medium resolution data sets with mandatory attenuation correction procedures is suitable for surveillance studies of homogeneous seagrass meadows with low interspersion of other benthic units such as corals, seaweeds.

Seven (7) species of seagrasses, were identified with diverse indices of species richness, abundance, dominance in the study area. T. hemprichii, and C. rotundata are dominant among the identified species. Variation of in the spatial structures also exist that re influenced by seagrass species and edaphic factors in the sediments.

Twelve coastal barangay are studied, eight of them were found to have seagrass and three were devoid of seagrass growth. Five (5) Species are identified it is enumerated as Halophila ovalis, Syringodium isotifolium, Tahalassia hemprechii, Cymodocea serrulata and Halodule uninervi.. An aggregated or clumped type of distribution are observed among the species..

Seven Species of were observed in the study area these were Enhalus acoroides, Halophila minor, and H.ovalis of family Hydrocharitaccae and Cymodocea rontundata, $C$. serrulata, Halodule pinifolia and unineervis of family Cymodoceaceae. The species are relatively diverse but they are classified as disturbed areas since it is located near human settlements and evidence of physical disturbance and pollution was visible.

13 species of Seagrass thrive along Palawan coastline. From the baseline data of average density of 16,566 the monitoring data reveals that there is the reduction of $49.7 \%$ of its current density that is mostly attributed to the sea level rise because of Climate Change. Hence, it is recommended to have intensive information campaign on the role of seagrass on the marine ecosystem and the inclusion of seagrass meadows as Marine Protection Area and incorporation of adapative measure to the effect of Climate Change on the marine resources.

Preliminary Assessment of Seagrass Resources in The Northern Philippines

Seagrass Diversity in Western And Eatern Sites of Igang Bay, Guimaras Philippines

Baseline Assessment of Seagrass Communities of Lubang and Looc Islands, Occidental Mindoro, Philippines
Seagrass in the N. Philippines was affected by warm, nutrient rich water of Kuroshio current. The productivity of the coastal resources of the region is fast declining due to increasing anthropogenic activities that threatens the coastal community including the seagrass meadows.

In the area there are nine identified species with a canopy height and percent cover that inversely interact. Its distribution is even after inter-monsoon at 0.71 and 0.12 in the eastern and western site respectively. With Thalassia hemprichi as the dominant species thriving in the area of study. Its diversity is seasonal and are determined through the percent cover, and indexes. This seasonality and dying-off the seagrass is dependent on the siltation, turbulence, and season present in the bay.

The seagrass beds in the area was described as multispecies and characterized as continues and patchy meadows with eight identified species with Thalassia hemprichii and Cymodocea rotundata as the most ubiquitous species. Kaingin poses the greatest threat to the seagrass ecosystem of the area with its long term domino effect of erosion and sedimentation on the seagrass beds. Quantization of hierarchy of anthropogenic disturbance in the fisheries practice must also be determined to measure degradation through fragmentation of this marine habitat.
Gejo Anna Geevarghese*, B. Akhil, G. Magesh, P. Krishnan, R. Purvaja, R. (2017)

Jess Jumawan, 2Michelle B. Bitalas, 2 Jezel Joy C. Ramos, 2Alvin Ray P. Garcia, 2Rosemarie S. Landero, 2 Jerell A. Cordero, 2Marc Noel V. Matela, 2Mary Ann D. Apostol, 2Renalyn B. Cataluña, (2015)

Orbita M.L.S. and Gumban, Nicole B. ,

2013

Marilou L. Meode, Estanlee B. Montes, Albert Q. Paloma, Jr., Journal of Science, Engineering Ma. Edlyn N. Panal and Nerissa M. Pesquera(2014)

Jesus E. Bream, 2013

Ame, Evelyn C. and Ayson, Jovita P, 2014

Alimen, RA.,Ong, HG.,Batuigas, RD.,Corpes, VO.,Esmenea, MMG., Ortizo, CD., Selerio, Jr. CM.(2010)

Genito, Genibeth E.; Nabuab, Fenelyn

M.; Acabado, Cristy S.; Albasin, Bella Sheila; Beldia Ii, Pacifico D., 2009

Generally, the studies on seagrass in the Philippines were conducted in Visayas and Mindanao that focuses more on the assessment, identification and inventory of the species in some of the coastal areas in the country. A total of 18 species are found the coastal waters all over the country. Some of the studies provides assessment on the index of distribution and seasonality of the seagrass species which are dependent on siltation, turbulence, and season present in the bay. Some illustrate the effect of climate change as the sea level rise and some provide manifestation of disturbed seagrass meadows due to anthropogenic activities especially those that are near the human settlements. Some stresses the need of quantifying the disturbance done by anthropogenic activities like kaingin and other fishery practices that causes marine habitat lost. The use of lightweight drones as an effort to investigate fragmentation within the seagrass meadows will the researchers measured in details the quality of the meadow in terms of the plant health. In the same manner, ecological studies on seagrass core microbiomes would show systematic taxonomy and functions profile that will be of help for maintain the health of seagrass holobiont. Digital mapping data set is suitable for surveillance of homogenous seagrass meadows even with the presence of other benthic species like corals and seaweed. Advanced technologies that can be adopted and finally be applied along the coast zone in the Philippines for effective assessment of the status of the country's seagrass meadows. 
Table 2. List of studies conducted for management of seagrass

\begin{tabular}{|c|c|c|}
\hline Studies & Findings and conclusion & Authors \\
\hline $\begin{array}{l}\text { Social-Ecological System } \\
\text { in Seagrass Ecosystem } \\
\text { Management at Kotania } \\
\text { Bay Waters, Western } \\
\text { Seram, Indonesia }\end{array}$ & $\begin{array}{l}\text { Social system pertains to the people } \\
\text { living around the ecological ecosystem } \\
\text { as the seagrass meadows. Both systems } \\
\text { influence one another in a way that } \\
\text { public perception of ecosystem goods } \\
\text { and services of seagrasses are rooted in } \\
\text { the social values. These values are } \\
\text { highly recognized in conservation, } \\
\text { resulting to ecological and economic } \\
\text { valuing of a natural resources that are } \\
\text { utilized for determining priority area in } \\
\text { management and planning of coastal } \\
\text { zones of a specific area. }\end{array}$ & Mintje Wawo (2017) \\
\hline $\begin{array}{l}\text { Practitioner's Perspective } \\
\text {,Strategies To Enhance } \\
\text { The Resilience Of The } \\
\text { World's, } \\
\text { Meadows }\end{array}$ & $\begin{array}{l}\text { Across the world, seagrass meadows are } \\
\text { under threats and to reverse this decline } \\
\text { some strategies can be useful. And one } \\
\text { of these are actions to protect the } \\
\text { ecosystem services provided by this } \\
\text { important marine habitat in order to } \\
\text { confer its resilience in this globally } \\
\text { changing environment. Moreover, } \\
\text { seagrass information campaign that } \\
\text { highlighting its importance and } \\
\text { sensitivity must be critically be done to } \\
\text { increase awareness among different } \\
\text { stakeholders of the community. } \\
\text { Significantly, seagrass conservation } \\
\text { needs improved policy and legislation } \\
\text { that supports local and regional } \\
\text { management to ensure long-term of } \\
\text { viability of seagrass meadows. }\end{array}$ & $\begin{array}{l}\text { Unsworth, LC and Unsworth, } \\
\text { RC.,(2016) }\end{array}$ \\
\hline $\begin{array}{l}\text { Seagrass significance for } \\
\text { a small-scale fishery in } \\
\text { the tropics: The require } \\
\text { for view organization. }\end{array}$ & $\begin{array}{l}\text { The highest aggregated benefits for a } \\
\text { community was provided by seagrasses } \\
\text { beds in terms of small scale fisheries, } \\
\text { but despite this significant contribution, } \\
\text { it has been overlooked when it comes to } \\
\text { policy and management, hence, it was } \\
\text { suggested to have a shift in } \\
\text { management approach under spinning } \\
\text { the fishery productivity and must } \\
\text { include socio-ecological component in } \\
\text { policy making for better protection of } \\
\text { this ecologically important marine } \\
\text { habitat. }\end{array}$ & $\begin{array}{l}\text { Dela torre-Castro, M.; Di Carlo, G.; } \\
\text { Jiddawi, N.;(2014) }\end{array}$ \\
\hline
\end{tabular}




\begin{tabular}{|c|c|c|}
\hline $\begin{array}{l}\text { Land use id better } \\
\text { predictor of tropical } \\
\text { segrass condition than } \\
\text { Marine protection }\end{array}$ & $\begin{array}{l}\text { Mitigating human activities adjacent to } \\
\text { the location of seagrass meadows my } \\
\text { increased conservation benefits, further, } \\
\text { terrestrial protection can be used a tool } \\
\text { in seagrass conservation, in a way that } \\
\text { will enhanced cooperation and } \\
\text { collaborations among environmental } \\
\text { advocates of terrestrial and marine } \\
\text { ecosystems, In the Philippines seagrass } \\
\text { conservation is still in the early stage, } \\
\text { especially for its practices for the } \\
\text { invasions of human action for land } \\
\text { conversion use that cause marine habitat } \\
\text { loss. }\end{array}$ & $\begin{array}{l}\text { Quiros, Al.; Croll D.;Fortes, MD.; } \\
\text { Raimondi, P.; ( 2017). }\end{array}$ \\
\hline $\begin{array}{l}\text { Small-scale fisheries can } \\
\text { reduce social } \\
\text { vulnerability: } \\
\text { comparative case study }\end{array}$ & $\begin{array}{l}\text { Seagrass bed provides primary and } \\
\text { supplementary income and an } \\
\text { opportunity for women to be included } \\
\text { in small scale fisheries. Despite this } \\
\text { importance, in the Philippines the focus } \\
\text { of MPAs were more on the } \\
\text { conservation of mangrove forest and the } \\
\text { coral reefs. It also suggests that } \\
\text { seagrass ecosystem may also be a part } \\
\text { of Marine Protected Areas because they } \\
\text { are high vulnerability and threatened } \\
\text { from anthropogenic and natural } \\
\text { degradation. Aside from the fact that } \\
\text { fishery industry from seagrass meadows } \\
\text { can generate } \$ 10 \text { US per day }\end{array}$ & $\begin{array}{l}\text { Quiros, AL.;Beck, MW.; Araw, A.; } \\
\text { Croll, AD.; Tershy , B. (2017) }\end{array}$ \\
\hline
\end{tabular}

Globally seagrasses are direct influence by the natural causes and human activities. That directly affects its status to be in a disadvantage of being degraded without the knowledge of mankind of the importance of the ecosystem services it provides. The economic valuation of the seagrass beds in the small scale fisheries with an estimated amount of $\$ 3000$ US of per month can be a baseline for its inclusion on the Marine Protected Areas with its high vulnerability due to the land use change.

Table 3: Artcles showing the need of conducting further studies for assessment and management of seagrass

Title of Article with the name of its Author

Recognizing the necessity for Indo Pacific seagrass conservation,

RKF Unsworth , 2010 services - What's next?

LM Nordlund - 2017

Effective monitoring to evaluate ecological restoration in the Gulf of Mexico, National Academies, 2017

\section{Justification for the need of the study}

Marine conservation priorities do not recognize the economic and ecological value of the goods and services that seagrasses provide in the Indo Pacific region. Dependency on coastal marine resources in the Indo- Pacific for daily protein needs is higher than the other region. Habitat loss may have negative consequences for food security in the region. Whether seagrass capital include an significant donation to this dependence remains mainly untested.

Areas to that need further investigation and study for understanding reseleince of seagrass 1) seagrass meadows ecosystems services variability; 2) Interconnectivity of this ecosystem with other marine habitats and 3) Improved information campaign on the importance of this ecosystem to the general public.

Performance monitoring is conducted to assess whether restoration objectives are being achieved. In particular, it must address to identify characteristics, spatial patterns in the distribution over annual scales, its composition and percentage cover, changes species composition as the water quality differs and factors affecting its growth. 
As described there is a limited information mentioned about the marine ecosystem that pertains to the significant contribution of seagrass compared to coral reefs and mangrove forest in the site. Hence, the need for a study on the seagrass in the area can help for the planning and management of the marine ecosystem of the place for its sustainability in the future.

\section{Concluding Remarks:}

Seagrass provides a variety of ecological functions that are not well understood by humans, resulting to being the least appreciated compared with the other marine ecosystems. The increasing rate of degradation of this coastal ecosystem and the services they can provide are severely influenced by human activities like coastal development, land reclamation, fish farming, land run off, solid waste disposal, lack of awareness of the importance of seagrass and the shortage of tool for information dissemination of the significant role of seagrass in our ecosystem. With several studies conducted in the Philippines about seagrass, it supports the idea that the country has diverse and abundant seagrass meadows that needs to be protected, conserved and managed as the literature reveals engaging in the development of studies of Seagrass Protection, Conservation and Management can be enhanced. Inclusion of human dimensions as well social vulnerability to understand appreciation of these ecosystem among the different stakeholders can be done. Mapping the places of species abundance and distribution as well as identification of its status for rehabilitation for effective management towards a resilient ecosystem as the world changes from natural and anthropogenic causes can be implemented through policy and ordinances. The economic valuation of ecosystem services in the small-scale fishery generated from seagrass amounting to \$10US per day is a benefit that can alleviate poverty will serve as a basis for policy makers to come up with a law and ordinances for protection, conservation and a management shift for the seagrass worldwide.

\section{References:}

[1] Alberto et al., (2015), Assessing Diversity and Phytoremediation Potential of Seagrass in Tropical Region International Journal of Plant, Animal and Environmental Sciences.

[2] Alimen et al., (2010), Sea Diversity in the Western and eastern Sites of Igang Bay, Guimaras Philippines,

[3] Ame EC and Ayson, JP( 2009), Preliminary Assessment of Seagrass Resources in The Northen Philippines. Kuroshio Science 3-1, 5561,2009 .

[4] Bagarinao, Teodora Uy (2015), Marine Biodervisity at the SEAFDEC/AQD research station in Iloilo and Guimaras , Philippines, https://hdll.handle.net/10862/2782

[5] BirdLife International (2018) Important Bird Areas factsheet: Ragay Gulf. Downloaded from http://www.birdlife.org on 13/05/2018.

[6] Bjork et al, 2008, Managing Seagrasses for Resilience to Climate Change,

[7] Brander et al., (2012), Ecosystem values for mangrove in Southeast Asia: A meta-analysis and Value transfer application, https://dx.doi.org/10.1016/j.ecoser.2012.06.003

[8] C.M. et. Al , 2008, The charisma of coastal ecosystems: Addressing the imbalance, ISSN: 15592723

[9] Cullen and Unsworth (2013), Seagrass Meadows, Ecosystem Services an Sustainability, http://dx.doi.org/10.1080/00139157.2013.785864

[10] de la Torre-Castro , 2017, Gender analysis for better coastal management - Increasing our understanding of social-ecological seascapes https://www.sciencedirect.com/science/article/pii/S0308597X16308259

[11] Dewsbury et al., (2016), A review of seagrass economic valuations: Gaps and Progress in valuation approaches, https://dx.doi.org/10.1016/j.ecoser.2016.02.010

[12] Dirkje Verhoeven (2016), The Role Of Nursery Habitats In The Effectiveness Of Marine Protected Areas In The Philippines

[13] Fortes, Miguel (2015), Historical Review of the Seagrass Research in the Philippines, https://www.researchgate.net/.../277094452

[14] Genito et al.,( 2009), Baseline Assessment of Segrass Communities of Lubang and Looc Islands, Occidental Mindoro, Philippines. The NAGISA WORLD CONGRESS: 53-64:2009

[15] Guannel et al.,(2016), The Power of Three :Coral Reefs, Seagrasses and Mangroves Protect Coastal Regions and Increase Their Resilience. PLOSONE|DOI:10.1371/journal.pone.0158094 July13,2016 
[16] http://wsa.seagrassonline.org/securing-a-future-for-seagrass/

[17] Honda et al., 2013 Habitat Use by Fishes in Coral Reefs, Seagrass Beds and Mangrove Habitats in the Philippines. http://journals.plos.org/plosone/article?id=10.1371/journal.pone.0065735

[18] Jumawan et al., (2015), Seagrass diversity and Structure along the coastal area in Paligue, Hagonoy, Davao del Sur, Philippines, AES BIOFLUX Advances in Environmental Sciences - International Journal of the Bioflux Society.

[19] Lina MtwanaNordlund ${ }^{a}$ Emma L.Jackson ${ }^{b}$ MasahiroNakaoka ${ }^{\mathrm{c}}$ JimenaSamper-Villarreal $^{\mathrm{d}}$ PedroBeca-Carretero ${ }^{\mathrm{e}} \mathrm{Joel}_{\text {C.Creed }}^{\mathrm{f}}$, Seagrass ecosystem services - What's next?, Marine Pollution Bulitten 1138(20180, pp145-151

[20] Meode et al., (2014), Distribution and Abundance of segrasses of Bontoc, Southern Leyte, Journal of Science and Engineering and Technology

[21] National Academies of Sciences, Engineering, and Medicine. 2017. Effective Monitoring to Evaluate Ecological Restoration in the Gulf of Mexico. Washington, DC: The National Academies Press. https://doi.org/10.17226/23476.

[22] Newmaster et al, (2011, Local Knowledge and Conservation of Seagrasses in the Tamil Nadu State of India, Journal of Ethnobiology and Ethnomedicine 2011, 7:37 http://www.ethnobiomed.com/content/7/1/37

[23] Nordlund et al.,(2017)Seagrass ecosystem services- What's next?, https:// dx.doi.org/10.1016/j.marpolbul.2017.09.014

[24] Nordlund et al, (2016) Seagrass Ecosystem Services and their Variability across Genera and Geographical Regions. PLos, https://doi.org/10.137/journal. Pone.0163091

[25] Orbita MLS and Gumban NB( 2013), Investigation of the community structure of seagrasses in the coastal areas of Iligan City , Mindanao, Philippines, AAB Bioflux, 2013, Volume 5 . Issue ,3. https://www.abb.bioflux.com.ro

[26] P. Saenger, D. Gartside and S. Funge-Smith( 2013), A review of mangrove and seagrass ecosystems and their linkage to fisheries and fisheries management

[27] Padilla, Jose (2008), Analysis of Coastal and Marine Resources: A Contribution to the Philippines Country Environmental Analysis

[28] Qiang He et al, (2014), Economic development and coastal ecosystem change in China' doi: 10.1038/srep05995

[29] Quiros, et al., (2018), Small Sccale seagrass fisheries can reduce social vulnerability: a comparative case study, Ocean and COasta Management 157(2018) 56-67

[30] Rice, Jake C. and Garcia, Serge M.( 2011) Fisheries, food security, climate change, and biodiversity: characteristics of the sector and perspective on emerging issues, https;//doi.org/10.1093/icesjms/fs041

[31] Ridley, Diana, 2008. The Literature review. A step by step guide for students. SAGe, 2008, pp1-184

[32] The 4th National Report To The Convention On Biological Diversity, (200), ASSESSING PROGRESS TOWARDS THE 2010 BIODIVERSITY TARGET:

[33] Tidwell TH and Allan GL (2001) Fish as Food: aquaculture's contribution, retrieved from https:// www.nbci nlm.nih.gov/pmc/article/PMC1084135/

[34] Tonette S. Rocco and Maria S. Plakhotonik, 2009, Literature Review: Conceptual Framework, and Theoretical Framework : Terms, Functions and and Distinctions: Sage Publication

[35] Unsworth et al, ( 2015) A framework for the resilience of seagrass ecosystems, https://dx.doi.org/10.1016/j.marolbul.2015.08.016

[36] Virginia Institute of Marine Science. (2011, March 24). Loss of plant diversity threatens Earth's life-support systems, experts say. ScienceDaily. Retrieved May 8, 2018 from www.sciencedaily.com/releases/2011/03/110303153116.htm

[37] Waycott et al., (2009), Accelerating loss of the seagrasses across the globe threatens coastal ecosystem www.pnas.org/cgi/content/full/09056106/DCSupplemental https://doi.org/10.1016/j.marpolbul.2017.09.014 pecification, IEEE Std. 802.11, 1997. 